\title{
A Tribute to Robert Hainault, 1940 - 2008
}

\section{Paul Catling, Gisèle Mitrow, and Jacques Cayouette}

Agriculture and Agri-Food Canada, Environmental Health, Biodiversity, Wm. Saunders Building, Central Experimental Farm, Ottawa, Ontario, K1A 0C6 Canada; e-mail: catlingp@agr.gc.ca

Catling, Paul, Gisèle Mitrow, and Jacques Coyouette. 2008. A tribute to Robert Hainault, 1940-2008. Canadian Field-Naturalist 122(1): 95-98

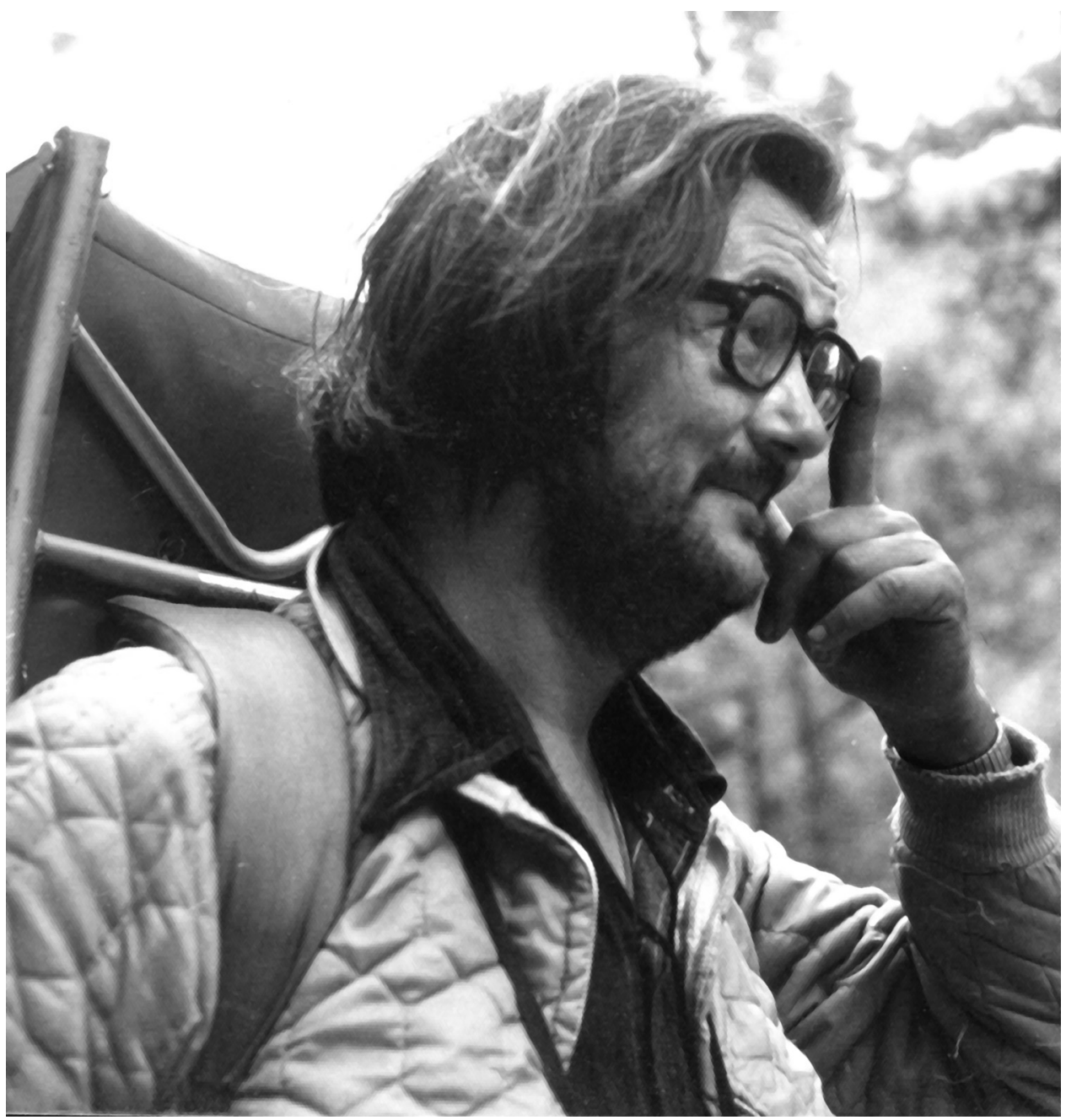

FIGURE 1. Robert Hainault 1980 or 1981 during a botanical survey of Cathedral Park, British Columbia. Photographer unknown.

Robert Hainault passed away on 11 June 2008 at age 68 in Brockville General Hospital following a lengthy illness. Robert is well known as one of a group of several students and associates of the distinguished Dr. Roland Ernst Beschel (1928-1971) of Queen's University, an unusually influential field biologist and conservationist (Andrews et al. 1971; Macpherson 1971; Smallman et al. 1991). Beschel was himself a student of Dr. H. Gams, a distinguished member of the Zurich-Montpelier school of plant ecology who specialized in mosses and lichens and wrote Kryptogamenflora von Mitteleuropa. The group that formed 
around Beschel was composed of university students, high school students, and retirees. They formed a functional unit reflecting Beschel's research interests and funding, with A. E. Garwood in charge of the finances. In addition to Hainault and Garwood, the group included S. P. Vander Kloet, P. Little, I. D. MacDonald, C. H. Zavitz, D. Cuddy, D. Webb, P. Webber, R. Norman and others. Many of this group were extraordinary field botanists and went on to play an important role in field biology, teaching and conservation planning across Canada. Robert Hainault is a fine example. He became influential as a teacher and a collector of specimens that can now be found in museums around the world. His distinguished academic ancestry is reflected in his paper on the geon concept (Hainault and Beschel 1968), which represents the Zurich-Montelier interpretation of plant communities.

Robert was born on 25 January 1940 in Marieville, just outside Montreal. As a young boy, sitting on the porch, he was fond of watching Montreal light up in the evening. It was in 1947 that Robert met Frère Roger Laurent (Figure 2), who was a student of the great Quebec botanist, Frère Marie-Victorin. Laurent would not answer Robert's question about a plant unless the correct Latin name was used. To the end of his life Robert Hainault was distressed by forgetting a Latin name. Thus, to some degree Robert was a product of the tradition in Quebec of Catholic priests and brothers teaching biological taxonomy and respect for nature in children's camps and various kinds of schools.

When he was 11 the family moved to Hawkesbury on the Ottawa River, Ontario. Here he met Mr. J. Ephrem Charlebois (1900-1993), a cobbler in nearby Montebello on the Quebec side of the river. Charlebois was an avid field botanist, always making botanical discoveries and corresponding and exchanging plant material with many of the influential botanists of the period, including Brother Rolland-Germain, S. J. Hay, H. Goutier at Montreal, R. Cayouette at Quebec City, S. Brisson at Sherbrooke, and W. G. Dore, B. Boivin and J. Cayouette at Ottawa. His herbarium went to Sherbrooke and is now at QFA. Charlebois was in a position to teach a young student a great deal. Robert first met him as a leader of the local Boy Scout group. He frequently hitched a ride to Montebello so that they could collect plants together. Robert soon became an accomplished botanist and he wrote an article about his collections and observations at Montebello in 1958 (Hainault 1959). During this period, Robert could not afford a copy of Flore Laurentienne but he could afford the beetle identification leaflets (later published together in Chagnon and Robert 1962) which were 25 cents each so he collected insects as well as plants. Without appropriate mounting and storage these collections were lost but nevertheless paved the way for a later important contribution to entomology.
In 1959-1960 Robert was in grade 13 at the Hawkesbury District High School. He had an exceptional science and biology teacher, Lionel Parisien. Mr. Parisien had heard rumors that Professor Beschel at Queen's University was looking for some students so he kindly drove Robert from Hawkesbury to Kingston to meet Beschel and discuss the possibilities of him continuing his education at Queen's with Beschel's help. This was a major step in Robert's life and career. Although he completed his university education (B.Sc.) at The University of Ottawa from 1961 to 1966, his association with Dr. Beschel continued.

During the summer of 1962 he worked with the Fisheries Research Board on Victoria Island in the western Canadian Arctic and collected plants there that were identified with Beschel's help. In the 1960s, Beschel sent Robert out to collect plants in the countryside around Kingston. He completed his field work on the flora of the eastern Lake Ontario islands during the summers of 1963 and 1964. At that time fishing boats were operating from Prince Edward Point and they took him out to the islands and picked him up. During his field trips he often pulled out a copy of Voltaire's Dictionnaire Philosophique. He later read everything available by and about Voltaire and he regularly visited the sculpture (a statue) of Voltaire by Jean-Antoine Houdon on display in the European Room at the National Gallery of Canada.

In 1965 Robert collected plants on Baffin Island at Inugsuin Fiord (a foiled attempt to use a native word since "Inugsuin" means "fiord" in inuit) as part of a cooperative study done by Queen's University and the Geographic Survey of Canada. A highlight of this trip was when a disgruntled RCMP officer pulled out a large manual and revealed a paragraph that indicated that a permit was necessary to collect plants in the Canadian Arctic. There was to be either a fine or a few weeks in jail. Robert contacted Garwood at Queen's University. He was advised by Garwood to take the jail term because the university had no extra funds. However, he was forgiven by the justice of the peace and resumed his collecting and cataloguing. Information from Robert's reports was used by other researchers studying arctic flora such as Rannie's (1986) study relating vascular plant diversity in the Arctic to summer air temperature and that of Beschel (1969) analysing arctic phytogeography.

In 1966 he returned to Queen's to begin working on his M.Sc. thesis project, "Flora of the islands of eastern Lake Ontario." He received the degree in 1969 and completed training as a teacher at McArthur College in 1970. From 1966 to 1968, Robert collected plants and documented flora in sites identified as significant as part of the International Biological Program (IBP). This was one of the first really important steps in identifying significant biodiversity on a very broad scale: its success depended on greatly skilled field biologists like Robert. During this period he col- 
lected plants in many areas around Kingston, particularly in Frontenac Park. This documentation contributed much to the protection of valuable biodiversity in the region.

The early 1970s saw Robert in Cathedral Park on the southern border of British Columbia. Here he spent several summers studying the flora and collecting plants. He made many discoveries that improved the general knowledge of plant geography. He also collected on the way (from Ottawa) to and from the park in places such as the Cypress Hills.

From 1970 to 1985 Robert taught high school biology and chemistry in east Ottawa first in Vanier at André Laurendeau and later at Belcourt. He also taught biology at night school. With enthusiasm and a special sense of humour he was very popular with his students, and some of them went on to become biologists. He influenced over 2000 students, providing more extensive information on biology than was available to most high school teachers at the time and advocating conservation. During this period he donated plant specimens to the Agriculture Canada and National Museum collections. During the summer of 1979 he worked with J. H. Soper at the National Museum doing several thousand plant identifications. He was encouraged and assisted by legendary Canadian botanists Bill Dore and Bernard Boivin at the Department of Agriculture herbarium (DAO), as were many younger botanists of that time.

While at Belcourt Robert met fellow teacher Patricia Harvey. A few years later they married. In 1985 they bought an old house in the country near Addison, north of Brockville, Ontario, where Robert lived until his death. In 1999 Robert was hospitalized for a knee replacement. While in hospital he contracted an unusual strain of bacteria resistant to antibiotic and became disabled. This made plant collecting difficult so he returned to his youthful pursuit of entomology. Insects could be conveniently caught in light traps. Obtaining scientific monographs with the help of scientists he became an expert on various groups of beetles. He discovered several beetles that had not been found in Canada previously and collected material that helped with the classification of a number of groups. His collections numbering at least a few thousand are in the Agriculture and Agri-Food Canada Insect collection (acronym CNCI) in Ottawa.

In 1974 Hainault's personal collection numbered about 7000 plant specimens of which half were from the Kingston and Lake Ontario regions (Boivin 1980), but other regions mentioned above were also extensively represented. As part of the exchange program, DAO distributed duplicates to many herbaria, especially those in the prairie provinces and to the BC Provincial Museum. Beschel and subsequent workers at Queen's University distributed duplicates to herbaria worldwide, including particularly Russia and Canada (including TRT and QFA). In a 1967 report, Hainault's

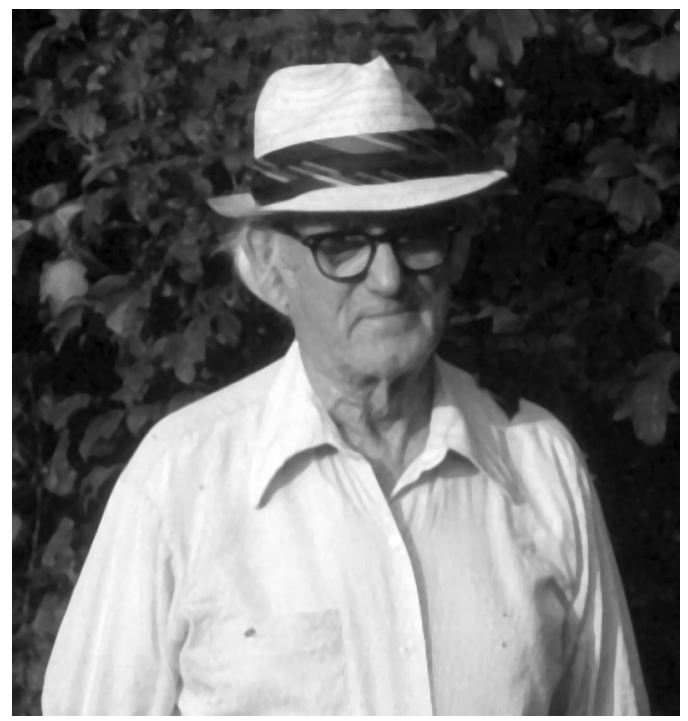

Figure 2. J. Ephrem Charlebois, 1979 at Montebello, Quebec. Charlebois was instrumental in Robert Hainault's developing interest in botany. Photograph by Sam Brisson.

specimens at the Fowler Herbarium at Queen's University numbered 3000 (Beschel 1967) making him second to Beschel with regard to numbers of recent collections at the time. His collections were important in completing the checklist of the vascular plants of the Kingston area (Beschel et al. 1970). For the most recent list of Kingston region plants see Crowder et al. 1996). His collections were the basis for his thesis on eastern Lake Ontario islands (Hainault 1968), a report on Baffin Island (Hainault 1966a), and another concerning the flora of Montebello (Hainault 1959). In October 2007, his personal collection (numbering about 10000 specimens at the time) was donated to National Plant Collection of Agriculture Canada (DAO) in Ottawa. Although mostly from the Kingston region, this collection also included specimens from British Columbia, Alberta, Saskatchewan, Ontario, Quebec, Labrador, New Brunswick, Greenland, Victoria Island and Baffin Island. The arctic and eastern Lake Ontario material is duplicated at Queen's University Herbarium $(\mathrm{QK})$, but his prairie provinces and western material is best represented at DAO. There were 550 specimens of mosses which were transferred to the Canadian Museum of Nature (these being mostly from Baffin Island, Ontario, and British Columbia).

All aspects of nature inspired Robert Hainault. He collected many books and gave them away to friends and colleagues. He also developed a very large collection of botanical photographs which he shared. His donated collections of over 10000 plant specimens (not including duplicates) as well as insects and mosses is a substantial contribution and his influence as a 
very effective teacher and colleague is an equally substantial achievement. No less impressive is the way in which he, with the help of his wife, Patricia Harvey, overcame a debilitating disease that has left him without the ability to walk or write, yet he continued to contribute as a field biologist.

\section{Acknowledgment}

Our thanks to Adele Crowder, Queen's University, Kingston, for proving valuable information.

\section{Literature Cited}

Andrews, J., J. Ives, and P. Webber. 1971. Roland E. Beschel, D. Phil. (1928-1971). Arctic and Alpine Research 3(2): 173-174.

Beschel, R. E. 1967. Kingston: Fowler Herbarium (QK). Pages 1-4 in Review of Canadian Herbaria (part 4). Edited by W. K. W. Baldwin. Mimeographed National Museum of Canada, Ottawa.

Beschel, R. E. 1969. Floristic relations of the nearctic islands. Botanicheskii Zhurnal (Journal Botanique de l'URSS) 54(6): 872-901.

Beschel, R. E., A. E. Garwood, R. Hainault, I. D. MacDonald, S. P. Vander Kloet, and C. H. Zavitz. 1970. List of the vascular plants of the Kingston region. Fowler Herbarium, Queen's University. 92 pages.

Boivin, B. 1980. Survey of Canadian Herbaria. Provancheria (Université Laval) 10: 1-187.

Chagnon, G., and A. Robert. 1962. Principaux coléoptères de la province de Québec. Université de Montréal.

Crowder, A., K. E. J. Topping, and J. C. Topping. 1996. Plants of the Kingston region: 1996. Department of Biology, Queen's University. 123 pages.
Hainault, R. 1959. Plants from Montebello. Federation of Ontario Naturalists Bulletin 85: 11-12.

Hainault, R. 1964. La flore de quelques îles du lac Ontario. Annales de 1'ACFAS 32: 38-39 [abstract].

Hainault, R. 1966a. Botany of Inugsuin Fiord area, Baffin Island, N.W.T. Pages 79-87 in Field Report, North-Central Baffin Island. Edited by O. H. Loken, Canada Department of Mines and Technical Surveys, Geographical Branch 905-18-8.

Hainault, R. 1966b. Some features of the flora of the islands of eastern Lake Ontario. Canadian Field-Naturalist 80: 69-73.

Hainault, R. 1968. Flora of the islands of eastern Lake Ontario. M.Sc. thesis, Queen's University, Kingston, Ontario. viii +175 pages.

Hainault, R., and R. E. Beschel. 1968. Application du concept du géon à la relation espèces - superficie. Annales de l'ACFAS 35: 52. abstract. [there is also a 17-page document entitled "Application of the geon concept to the species: area relationship" which was distributed. Copies at Fowler Herbarium and AAFC vascular plant herbarium].

Macpherson, A. H. 1971. Roland Ernst Beschel (19281971). Arctic 24(4): 316.

Rannie, W. F. 1986. Summer air temperatures and number of vascular species in Arctic Canada. Arctic 39(2): 133137.

Smallman, B. N., H. M. Good, and D. S. West. 1991. An academic history of Queen's biology, 1885-1965. Queen's University, Kingston.

Received 20 November 2007

Accepted 19 August 2008 